\title{
For a European political space
}

\section{Nadia Urbinati}

Abstract: European nationalists capitalise on the socio-economic dissatisfaction of their citizens when they claim that open borders are the main cause of the decline in job opportunities and the wellbeing of the middle class. Their rhetoric 'against' migrants puts their adversaries in the position of needing to propose solutions, of mobilising 'for'. The challenge is demanding, but cannot be evaded. This paper argues that redirecting the debate on the problem of social regression is essential in order to deflate the obsessive talk on immigration; because it is precisely the fostering of this obsession by xenophobic nationalists that galvanises audiences.

Keywords: anti-immigration rhetoric, European Union, right-wing nationalism, sovereignism.

Author: Nadia Urbinati is Professor of Political Theory in the Department of Political Science, Columbia University. Her latest books include Democracy Disfigured: Opinion, Truth and the People (2014, Harvard University Press), and The Tyranny of the Moderns (2015, Yale University Press). She is currently leading the Feltrinelli Foundation's research on democratic transformations, and has recently completed a book manuscript (forthcoming with Harvard University Press) titled Me the People: How Populism Transforms Democracy.

nu15@columbia.edu

(C) The author(s) 2020. This is an open access article licensed under a

Creative Commons Attribution-NonCommercial-NoDerivs 4.0 Unported License 
From the Vistula to the Seine to the Po, European nationalist politicians use the rhetoric of fear to capitalise on the socio-economic dissatisfaction of their citizens. They claim that immigration and open borders are the main cause of the growth of inequality, the decline in job opportunities and the erosion of the middle class, even more than Brussels' techno-bureaucrats and the European Central Bank, their traditional scapegoats, making immigration and borders the central issues not simply of individual states but of Europe as a whole. Their rhetoric 'against' migrants puts their adversaries in the position of needing to propose solutions, of mobilising 'for'. The challenge is demanding but cannot be evaded. Redirecting the debate on the problem of social regression is essential in order to deflate the obsessive talk on immigration; because it is precisely the fostering of this obsession by xenophobic nationalists that galvanises audiences.

Although Euroscepticism is as old as the European integration project itself, the recent march towards European nationalism at the continental level began with the referendum against the EU Treaty in France and the Netherlands (2005), becoming more widespread and radical in some subsequent national elections during the decade of financial crisis that started in 2008. An increase in electoral success for nationalist parties has been witnessed in many EU member states (for example, Denmark, Finland, Poland, Hungary, Austria, Italy, Spain) although in some cases support for these parties may have fallen back (Austria and Hungary most recently). Hungary has been at the forefront of the new Euronationalist project, with Viktor Orbán's government not only identifying anti-immigration policies with the protection of European values (such as, in his view, Christianity and whiteness) but also building an electrified fence on the border with Serbia and Croatia to keep out migrants from Asia.

While previously nationalism was directed against the European Union, following the high peak of migration in 2015 and then the Brexit referendum in 2016, two phenomena emerged: (a) nationalist issues started attracting political leaders beyond traditional right-wing parties; and (b) nationalist leaders started projecting themselves as European leaders, not merely national. It would be reasonable to say that the 2015 flows of migrants from Africa and the Middle East and then the Brexit referendum had a deterrent effect - they induced former enemies of Europe to adopt a strategy for the conquest of Europe instead. Skepticism is now directed at the project of a federal union, but not at the voluntary association of European states in order to better further their interests. In an interview with the Corriere della Sera on 15 May 2019, Marine Le Pen, leader of the Rassemblement National, said that right-wing parties share the same vision of Europe on 'sovereignty, the peoples' right to self-determination and voluntary cooperation'. ${ }^{1}$

${ }^{1}$ Le Pen (2019). 
Let us go back to the above-mentioned two points and see how 'positive' rhetoric can be opposed to nationalists' 'negative' rhetoric. As to point (a), we can see mainstream politicians adopting aggressive policies of containing immigration, for example in France under Macron and in Italy during the centre-left government prior to 2018. Thus, the Italian authorities set up the Maritime Rescue Coordination (MRCC) to police rescue missions, which on 1 August 2017 seized the German NGO vessel Iuventa, with migrants on board, on the pretext of combatting human trafficking. The subsequent court case highlighted the moral choice involved between rescuing people and leaving them to their fate. The issue of migration is closely connected to international relations, and puts in question the performance of the EU, its inability to devise an international politics of economic cooperation with sending countries and strategies of conflict resolution aimed at assisting and supporting the process of stabilisation in Libya and other countries in the region. This would answer the nationalists' 'against' rhetoric in a 'positive', constructive way.

As to point (b), which should concern us the most, in the run-up to elections for the European Parliament in May 2019, the leaders of national-sovereign parties formed an alliance in a 'populist international' project supported by Steve Bannon. They were able to present the issue of borders as the only theme permeating political discourse in Europe today, from right to left, even though it is of course the right wing that is primed to capitalise the most from it. The development of the ideology of 'sovereignism' represents this situation well: it started as a claim by the nation-states to control over their borders and gradually became a claim of continental acquisition of power over the borders of Europe. The rhetoric of more sovereignty was used by, for example, Matteo Salvini, to make the case for a new European Union that supports the nationalist policies of its member states. Making the EU a sealed bloc of states founded on a few clear objectives resonates with themes embedded in the history of the continent: the centrality of the white race, the Christian religion and the well-being of some Europeans.

The policy implications of nationalism's possessive nature ('Italians first' or 'we want our sovereignty back') are unpredictable. The approach may be played out in protectionist ambitions, but it may also appear in libertarian claims. In general, nationalist leaders do not embrace rhetoric that rejects the individual liberties that civil rights brought to their people (although they thunder against the 'inimical' press). But they $d o$ use the language of rights in a way that subverts its proper function: first, to state and reclaim the absolute power of the many over their 'civilisation', and thereby over rights, and then to make this power one that only the represented people ('our national compatriots') possess and are allowed to enjoy. The suspension of universalism is a direct consequence of a possessive and thus relative conception of rights. This is the discourse lurking beneath the 'sovereignist' argument used by European nationalists. 
A 'positive' answer to this 'against' rhetoric would entail going back to the basic ideals of human and civil rights upon which the EU was constructed and that are still central in the EU institutions. The European Union has founding principles and directives to combat the political project of exclusionary nationalism. What Salvini and Orbán say to their compatriots will be repeated on a European scale if their politics succeed: enough of 'good-heartedness', enough of open borders (which have never actually been truly open), enough of the pretensions of the EU bureaucracy. A 'positive' answer to this 'negative' rhetoric is possible but demands an exercise of political will; it cannot simply come from the assumption that the EU will survive by inertia. A 'positive' rhetoric demands a critical analysis of the factors that have facilitated the emergence of nationalism. It would be myopic to think that the idea of an EU xenophobic sovereignty is simply due to the malevolence of the right.

The factors that explain the turn to the right of political discourse are multifaceted. The EU had already started toning down the project of political unification before the financial crisis began. Then over the course of the crisis, the institutions most distant from the citizens, those not directly elected, acquired more decision-making power and even representative power. The EU body most directly connected to electoral consent (the Parliament) does not have an equally powerful voice as the European Central Bank and the European Commission. The institutions that have gained most authority during this decade of crisis are either largely not bound by the political consensus (European Central Bank) or are more directly representatives of the interests of the member states (European Commission). In addition, intergovernmental agreements have achieved momentum, which means that the interests of each state (sometime of the economically strongest states) are pursued more energetically than are continental politics of integration. What is left of the project of a united Europe envisaged by the Treaty of Lisbon? Not very much. That treaty reflected the ambition of the founders: a continent that was committed to promoting social policies and subsidiary responsibility to regions and local governments. That continental project also included concern for hospitality to non-European people, particularly those escaping from wars and persecution.

The ideal of inclusion was an essential part of the project of constructing a European citizenship as 'the extension of citizenship beyond the State as a matter of legal reality' and a challenge to the privileged link between 'nationhood' and 'citizenship' upon which democracy developed, according to Ulrich Preuss. ${ }^{2}$ And yet, Europe today does not have a common policy on asylum or hospitality, and it has no requirement for humanitarian corridors. It has also abandoned the project of a European citizenship defined by rights and duties, participation and belonging to a common

${ }^{2}$ Preuss (1998). 
political space. These rights - economic, social and political — concern not just those people who belong to the member states but all EU citizens. Today, the recognition of these rights remains fragmented, incomplete and fragile. To offer a solid basis for the sustainable integration of Europe, EU rights must be defended, equalised and made permanent by removing limits on the application of the Charter of Fundamental Rights of the EU and allowing for a more equal and direct access to justice for all citizens and residents. Permanent legal residents in the European territory must be granted as much participation as possible at every level for the government of common interests and the protection of their rights. European democrats should commit to this project and oppose the 'against' nationalist rhetoric with 'positive' answers. The paradox of the nationalist ideology is to present itself to public opinion 'as if' there was a political Europe to be opposed with another one. The fact is that a political Europe does not exist.

\section{REFERENCES}

Le Pen, M. (2019), 'Interview with Marine Le Pen', Corriere della Sera, 15 May. https://video.corriere.it/europee-pen-a-salvini-mandato-portavoce-creare-grande-gruppo-europa/ d7745f86-5fbf-11e9-b974-356c261cf349

Preuss, U. K. (1998), 'Citizenship in the European Union: A Paradigm for Transnational Democracy?', in Daniele Archibugi, David Held \& Michael Köhler (eds), Reimagining Political Community: Studies in Cosmopolitan Democracy (Cambridge, Polity Press), 138-151.

To cite the article: Nadia Urbinati (2020), 'For a European political space', Journal of the British Academy, 8(s1): 13-17.

DOI https://doi.org/10.5871/jba/008s1.013

Journal of the British Academy (ISSN 2052-7217) is published by

The British Academy, 10-11 Carlton House Terrace, London, SW1Y 5AH

www.thebritishacademy.ac.uk 
